\title{
KAJIAN DENDRIMER (Poly)amidoamine (PAMAM) GENERASI 4 SEBAGAI TEMPLATE DALAM PEMBENTUKAN NANOPARTIKEL SECARA IN SILICO
}

\author{
Yurika Sastyarina ${ }^{1)}$, Zuhrotun Nafisah ${ }^{2)}$, Muhammad Yusuf ${ }^{2)}$, Martalena Ramli ${ }^{3)}$, \\ Abdul Mutalib $^{2)}$, Ukun Soedjanaatmadja ${ }^{2)^{*}}$ \\ Fakultas Farmasi Universitas Mulawarman Samarinda, 751191) \\ Departemen Kimia Fakultas Matematika dan Ilmu Pengetahuan Alam, Universitas Padjadjaran \\ Bandung 453632) \\ Pusat Teknologi Radioterapi Radiofarmaka BATAN, Puspitek Serpong ${ }^{3)}$ \\ *Corresponding author: ukun_28@yahoo.co.id ; ukun@unpad.ac.id
}

\begin{abstract}
Dendrimers are a class of highly branched synthetic polymers that has spherical form consist of three components: core, branch and terminal functional groups. One of dendrimer that has been commercialized is (Poly)amidoamine (PAMAM). PAMAM dendrimer used as a template in the preparation of gold nanoparticles. This research was studied the streched cavities of (Poly)amidoamine (PAMAM) dendrimer generation 4 using in silico method. Structure of (Poly) amidoamine (PAMAM) dendrimers generation 4 downloaded from Building Toolkit (DBT) Library and before the simulation structure was prepared. Then molecular dynamics simulations run using the AMBER program at $37^{\circ} \mathrm{C}$ in aqueous conditions. From analysis, obtained that the furthest distance of streched cavities at the closest distance from the core, region between residues 2 and 3 is $23.696 \AA$ and at the terminal region between residues 100 and 122 is $58.045 \AA$
\end{abstract}

Keyword: Dendrimer, PAMAM, nanoparticle, in silico

\begin{abstract}
ABSTRAK
Dendrimer merupakan polimer sintetik dengan rantai bercabang berulang berbentuk sferis yang terdiri dari tiga komponen, yaitu gugus inti, rantai cabang dan gugus terminal fungsional. Salah satu dendrimer yang telah dikomersilkan adalah (Poly)amidoamine (PAMAM). Dendrimer PAMAM dapat menjadi template pada pembuatan nanopartikel emas. Penelitian ini dilakukan untuk mengkaji kemampuan meregangnya rongga suatu dendrimer PAMAM generasi 4 dengan menggunakan metode in silico pada suhu tubuh dan keadaan berair. Struktur PAMAM generasi 4 diunduh melalui Dendrimer Building Toolkit (DBT) Library dan dilakukan preparasi file sebelum simulasi dan dilakukan simulasi dinamika molekul menggunakan program AMBER pada suhu $37^{\circ} \mathrm{C}$ dan keadaan berair. Dari hasil analisis didapat jarak regang terjauh pada daerah dekat inti antara residu 2 dengan 3 sebesar 23,696 sedangkan pada daerah terminal antara residu 100 dengan 122 sebesar 58,045 A.
\end{abstract}

Kata Kunci: Dendrimer, PAMAM, nanopartikel, in silico 


\section{PENDAHULUAN}

Penggunaan nanoteknologi dalam diagnosis dan pengobatan berkembang semakin pesat. Salah satunya yaitu penggunaan nanopartikel emas yang mana telah dikembangkan untuk berbagai terapi seperti pengobatan dan diagnosis pada penyakit kanker. Dalam pembuatan nanopartikel sebagai suatu sistem pelepasan obat dan diagnosis memiliki beberapa keuntungan yaitu ukuran dan karakteristik permukaan yang pelepasannya dapat dirancang dan dikontrol selama penghantaran dan dapat dijadikan penghantaran tertarget ke sel melalui penambahan ligan. Tetapi disamping kelebihan dari nanopartikel terdapat pula kelemahan nanopartikel yaitu dapat terjadi agregasi dan aglomerasi selama penghantaran (1). Salah satu sistem penghantaran dalam nanopartikel yaitu sistem polimer seperti dendrimer. Nama "dendrimer" berasal dari kata Yunani 'dendron', yang berarti pohon dan referensi struktur molekul-molekul berupa 'cabang' yang keluar dari inti molekul. Dendrimer merupakan polimer dengan rantai bercabang berulang berbentuk sferis yang terdiri dari tiga komponen, yaitu gugus inti, rantai cabang dan gugus fungsi terminal yang dapat dikonjugasikan dengan berbagai ligan. Salah satu tipe dendrimer yang telah dikomersilkan adalah (Poly)amidoamine (PAMAM) oleh Tomalia et al (2) pada tahun 1985 PAMAM dapat disintesa menghasilkan beberapa generasi, dimana tiap generasi secara proporsional mengalami peningkatan pada ukuran dan berat molekulnya. Dendrimer berbasis (Poly)amidoamine (PAMAM) adalah kandidat utama selain sebagai template juga bersifat stabilizer dalam pembentukan nanopartikel emas $(3,4)$. Selain itu, (Poly)amidoamine (PAMAM) yang mengenkapsulasi nanopartikel emas juga berfungsi sebagai drug delivery, karena sifatnya yang spesifik pada sel kanker dan biocompatible dalam tubuh. Hal ini menjadi keuntungan dalam penggunaan secara klinik selain kelarutan yang tinggi dalam larutan, struktur dendrimer yang mampu melipat dapat membentuk nanopartikel dengan bentuk yang unik dan nanopartikel emas terjerat dalam rongga dendrimer sehingga melindungi dari kemungkinan reduksi yang terjadi dalam penghantarannya ke sel target dan mampu membentuk sistem biokompatibel sehingga dendrimer dapat menjadi sistem pembawa ke target (5, Esfand \& Tomalia, 2001). Telah banyak dilakukan penelitian mengenai struktur dendrimer secara in silico atau komputasi, baik karakteristik dalam pembuatan dendrimer maupun sifat-sifat fisika dan kimia dendrimer dari berbagai generasi $(7,8)$. Dalam penelitian ini kami mengkaji secara in silico atau kimia komputasi mengenai kemampuan meregangnya rongga atau cavities suatu dendrimer (Poly)amidoamine (PAMAM) generasi 4 yang mana hal ini penting diketahui karena berkaitan dengan kuantitas dari emas yang "terjerat" dalam rongga PAMAM sehingga dapat menjadi acuan dalam proses pembuatan nanopartikel emas secara eksperimental.

\section{CARA KERJA}

\section{Bahan dan Alat}

Bahan dalam penelitian ini adalah bentuk struktur molekul (Poly)amidoamine (PAMAM) Generasi $4 \mathrm{pH}$ netral yang diunduh dari Dendrimer Building Toolkit (DBT) Library (9). Sedangkan Alat-alat yang digunakan dalam penelitian ini dibagi dalam 2 kelompok, yaitu perangkat keras (hardware) dan perangkat lunak (software). 
Perangkat keras terdiri dari seperangkat PC (Personal Computer) dan perangkat lunak berupa sofware AMBERTools 15 dan Discovery Studio 4.1 Visualizer

\section{Metode Penelitian}

Sebelum dilakukan simulasi dinamika molekul dengan menggunakan AMBERTools15. Tahapan selanjutnya diminimisasi diawali menggunakan algoritma steepest descent kemudian diteruskan menggunakan algoritma conjugate gradient hingga akhir minimisasi. Setelah itu dilakukan proses heating, equilibrium dan, production. Analisis untuk melihat keregangan rongga atau cavity stretch dari PAMAM generasi 4 dilakukan pada tahap production dimana untuk pengukuran cavity stretch struktur PAMAM generasi 4 dibagi menjadi dua bagian dengan bantuan visualisasi Discovery Studio 4.1 Visualizer yaitu bagian yang dekat dengan inti dan bagian yang dekat dengan ujung terminal dan masing-masing bagian dibagi menjadi empat daerah pengukuran dan dilakukan proses simulasi produksi selama 6 ns dan dilakukan analisis kuantitatif RMSD serta RSMF dari tahap production untuk melihat kestabilan konformasi dendrimer PAMAM generasi G4. Data yang diperoleh dibuat grafiknya ini dapat dilihat trayektorinya dan keadaan yang paling stabil dapat ditentukan. Trayektori ini dilakukan dalam berair pada suhu tubuh $37^{\circ} \mathrm{C}$.

\section{HASIL DAN PEMBAHASAN}

\section{Preparasi file dinamika molekul}

Dendrimer merupakan polimer dengan rantai bercabang berulang berbentuk sferis . Struktur PAMAM Generasi $4 \mathrm{pH}$ netral dalam penelitian ini diunduh melalui Dendrimer Building Toolkit Library dimana diketahui PAMAM generasi 4 memiliki jumlah atom sebanyak 2308 dan 64 nitrogen pada daerah terminal
$(7,9,10)$. Dengan menggunakan sofware Discovery Studio 4.1 Visualizer dapat diketahui residu dari PAMAM Generasi 4 yang mana residu tersebut dibagi menjadi tiga yaitu bagian residu gugus inti, residu rantai cabang yang terulang dan terkait inti serta residu gugus amin terminal fungsional.

Pada proses sebelum minimisasi energi, dilakukan solvasi secara eksplisit dengan penambahan air menggunakan waterbox model TIP3P yang terdapat pada sofware AMBER 15 dimana solvasi ini bertujuan untuk menciptakan suasana seperti tubuh manusia, yang kandungan terbesarnya adalah air. Selanjutnya dilakukan dilakukan penambahan muatan ion negatif $\mathrm{Cl}^{-}$sebanyak 64 ion dengan menggunakan forcefield GAFF agar didapat suasana netral.

Proses berikutnya adalah minimisasi energi yang bertujuan menghindari kontak van der walls yang tidak sesuai dan untuk meminimalkan efek sterik berenergi tinggi dari struktur (11). Hasil dari minimisasi didapatkan energi potensial terendah bagi sistem

\section{Simulasi Dinamika Molekul}

Simulasi dinamika molekul ini dilakukan dengan menggunakan ff14SB sebagai medan gaya. Molekul direpresentasikan sebagai model seluruh atom klasik (classical all-atom model), dimana seluruh interaksi intramolekular dan intermolekular termasuk molekul pelarut direpresentasikan oleh medan gaya mekanika molekular. Hasil simulasi dinamika molekul ini berupa data seperti energi total, energi kinetik dan energi potensial yang mana diambil struktur dengan energi relatif paling rendah untuk tahap berikutnya. Setelah dilakukan proses minimisasi energi, dilakukan simulasi dinamika molekul pada temperatur $310 \mathrm{~K}$, yaitu temperatur suhu tubuh dan pengaturan waktu selama 6 ns dilakukan 
pada kolom run untuk tahap ekuilibrium dimana merupakan proses pemerataan kerapatan posisi atom pada semua sistem dan kondisi rileks akibat proses pengekangan akibat proses pemanasan. Didapat pada rentang waktu terjadi peningkatan $0-60,7 \mathrm{kcal} / \mathrm{mol}$ pada energi total. Hal ini disebabkan struktur senyawa masih bergerak dinamis mencari konformasi geometri yang paling ideal yang ditunjukan dengan peningkatan nilai energi potensial dan energi totalnya. Sedangkan, pada waktu 90,3 ps mulai terjadi kestabilan energi total. Ini mungkin disebabkan senyawa telah mulai menemukan konformasi geometri yang ideal, yang ditandai dengan kestabilan nilai energi potensial dan energi totalnya (Gambar 1) Energi total sendiri merupakan penjumlahan energi kinetik dan potensial.

Tahapan selanjutnya yaitu tahap produksi yang menggambarkan konformasi molekul yang terjadi selama proses simulasi dinamika molekul dan dilakukan analisis cavity stretch berupa jarak-jarak kerenggangan suatu cavity atau rongga dendrimer yang dibagi dalam 4 daerah (Gambar 2)

Pada pembuatan nanopartikel emas dengan menggunakan dendrimer PAMAM sebagai template dimana partikel emas "terjerat" dalam rongga-rongga pada PAMAM maka dari itu diperlukan data sejauh mana rongga-rongga dalam dendrimer PAMAM Generasi 4 dapat meregang sehingga dapat memperkirakan jumlah partikel emas yang masuk ke dalam rongga dendrimer tersebut. Dalam penelitian ini diambil 4 data mulut rongga di daerah terminal dendrimer dan 4 data cabang bagian dalam rongga dendrimer. Sedangkan untuk daerah dalam rongga diwakili oleh jarak antara atom oksigen residu 2 dengan 3; 2 dengan 4; 3 dengan 4 dan 5 dengan 9 yang dekat dengan inti (Gambar 3 \& 4).

Untuk daerah terminal diwakili oleh jarak antara atom residu oksigen 68 dengan 84; atom nitrogen 88 dengan 115; 71 dengan 113; dan 100 dengan 122 (Gambar $5 \& 6)$

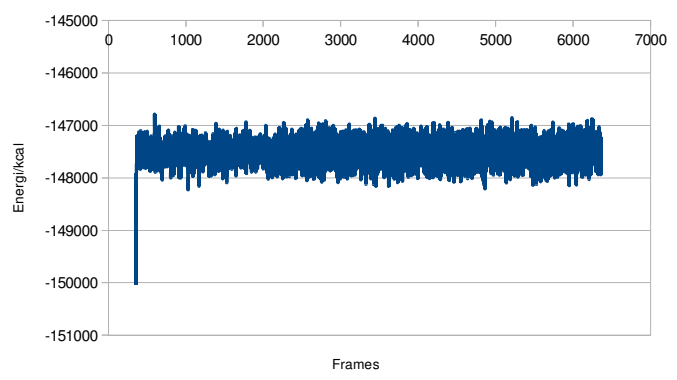

Gambar 1. Trayektori energi total pada proses pemanasan $310 \mathrm{~K}$ dan ekuilibrium 
Kajian Dendrimer (Poly)Amidoamine (Pamam) Generasi 4 Sebagai Template Dalam Pembentukan Nanopartikel Secara In Silico

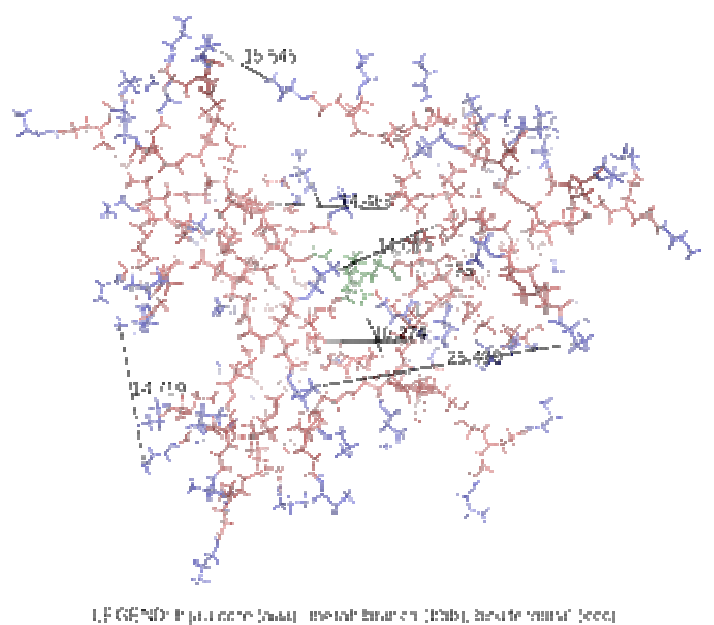

Gambar 2. Visualisasi 2D struktur Dendrimer PAMAM Generasi 4

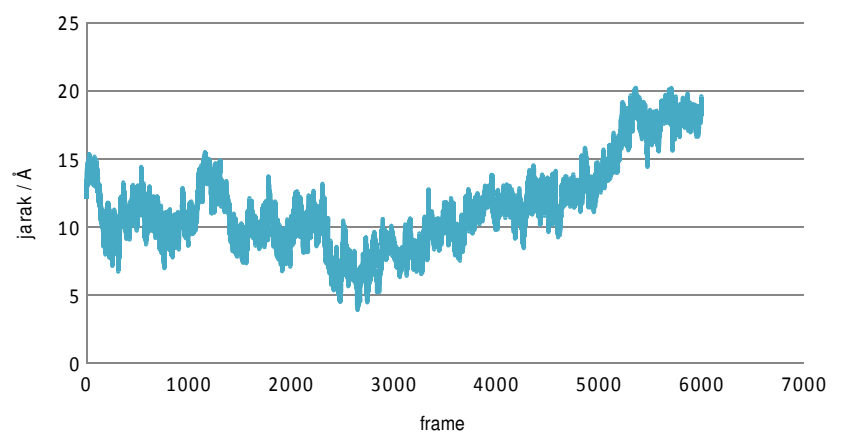

Gambar 3 Fluktuasi jarak atom oksigen antara residu 2 dan 3 yang dekat dengan inti

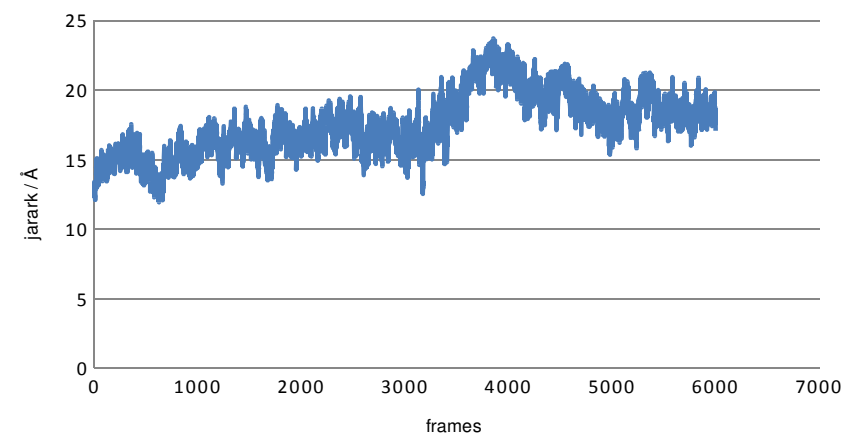

Gambar 4 jarak antara residu 2 dan 4 yang terletak dekat dengan inti 
Kajian Dendrimer (Poly)Amidoamine (Pamam) Generasi 4 Sebagai Template Dalam Pembentukan Nanopartikel Secara In Silico

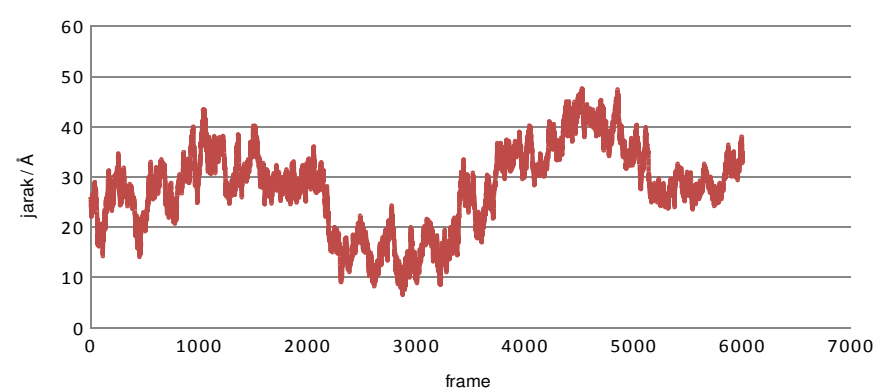

Gambar 5 Jarak atom oksigen antara residu 68 dan 84 di daerah terminal

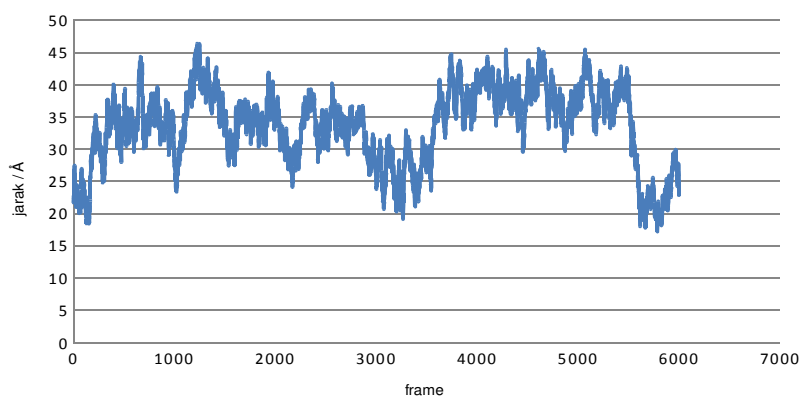

Gambar 6 Jarak atom oksigen antara residu 71 dan 113 di daerah terminal

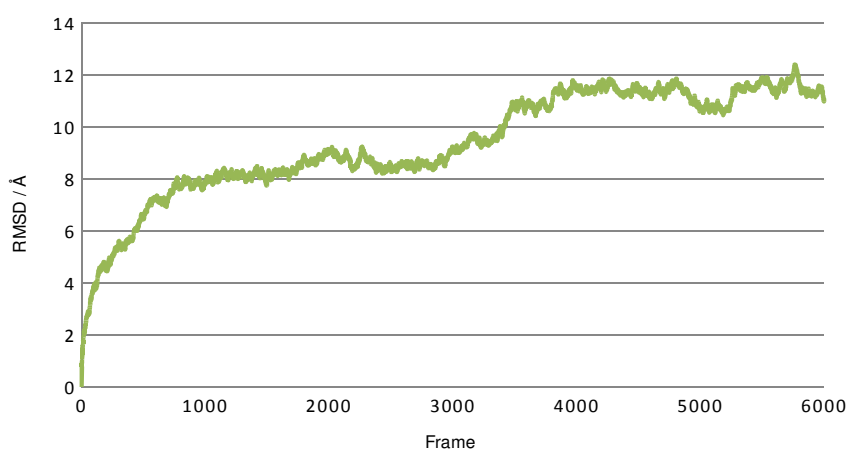

Gambar 7. Trayektori nilai RMSD pada tahap produksi dari simulasi molekul dinamika struktur PAMAM generasi 4

Dari hasil seluruh pengamatan didapat pada daerah dekat inti jarak renggang rongga terjauh untuk residu 2 dengan 3 sebesar 23,696 ̊; 2 dengan 4 sebesar 20,2041 A; 3 dengan 4 sebesar 17,2811 dan 5 dengan 9 sebesar $23.6872 \AA$. Sedangkan regang terendah untuk residu 2 dengan 3 sebesar 11,9255 ̊; 2 dengan 4 sebesar 3,9285 $\AA$; 3 dengan 4 sebesar $7,3412 \AA$ dan 5 dengan 9 sebesar 10,3824 $\AA$. Sedangkan pada daerah terminal jarak renggang rongga terjauh untuk residu 68 dan 84 sebesar 47,6762 A; residu 188 dan 115 sebesar 37,9693 $\AA$; residu 71 dan 113 sebesar 46,3716 $\AA$; residu 100 dan 122 sebesar 58,045 Å. Sedangkan regang 
terendah untuk residu 268 dan 84 sebesar $6,5222 \AA$; residu 88 dan 115 sebesar $4,2463 \AA$; residu 71 dan 113 sebesar $17,2109 \AA$; residu 100 dan 122 sebesar $24,7823 \AA$. PAMAM generasi 4 dapat dilihat dari hasil simulasi dinamika berupa frame konformasi yang dilihat tiap tahap. Pada penelitian ini dilakukan sebanyak 6000 frame. Adanya molekul pelarut juga berpengaruh terhadap konformasi molekul PAMAM generasi 4.

Selain itu dilakukan analisis kuantitatif Root Mean Square Deviation (RMSD) untuk penentuan stabilitas konformasi. Perhitungan RMSD dilakukan bila masing-masing struktur memiliki jumlah dan jenis residu yang sama (Maiorov \& Gordon, 1994). Gambar 7 merupakan frame konformasi berupa nilai RMSD yang dihitung melalui analisis pada sofware AMBER. Trayektori nilai RMSD pada tahap produksi dari simulasi molekul dinamika struktur PAMAM generasi 4

\section{KESIMPULAN}

Pada penelitian ini mengkaji struktur dendrimer PAMAM generasi 4 menggunakan metode in silico atau dikenal dengan komputasi dengan melihat jarak renggang rongga-rongga atau cavity dari empat daerah yang berbeda yang dapat menjadi template bagi pembuatan nanopartikel emas dimana dari hasil pengamatan didapat jarak regang terjauh pada daerah dekat inti yaitu jarak atom oksigen antara residu 2 dengan 3 sebesar 23,696 Å sedangkan pada daerah terminal antara residu 100 dengan 122 sebesar $58,045 \AA$.

\section{UCAPAN TERIMAKASIH}

Terima kasih diucapkan kepada Fakultas Farmasi Universitas Mulawarman yang turut serta membiayai penelitian ini dan Universitas Padjadjaran atas penyediaan fasilitas dalam penelitian ini.

\section{DAFTAR PUSTAKA}

1. Mohanraj, V.J. \& Chen, Y., 2006. Nanoparticle. A review Tropical Journal of Pharmaceutical Research 5 (1) : 561-573

2. Tomalia D.A., Baker, H., Dewald, J., Hall, M., Kallos, G., Martin S., Roeck, J., Ryder, J. \& Smith P. A., 1985. New Class of Polymers - Starburst-Dendritic Macromolecules. Polymer Journal 17:117-132.

3. Chan, H.K., \& Kwok, P.C.L., 2001. Production Methods For Nanodrug Particles Using The Bottom Up Approach. Advance Drug Delivery Reviews 63:406-416.

4. Dietrich, S., Schulze, S., Hietschold, M., \& Lang, H., 2011. Au Nanoparticles Stabilised by PEGylated Low Generation PAMAM Dendrimers:Design, Characterisation and Properties. Journal of Colloid and Interface Science

5. Caminade, Anne-marie, Turrin, C.O., Laurent, R., \& Ouali, A., Delavaux-nicot, B., 2011. Dendrimers Towards Catalytic, Material, adn Biomedical Uses. United Kingdom : John Wiley \& Sons, Ltd.

6. Esfand, R., \& Tomalia, D.A., 2001. Poly(amidoamine) (PAMAM) Dendrimers from Biomimicry to Drug Delivery and Biomedical Application. Drug Discovery Today 6: 427-436.

7. Maiti, P. K., Cagin, T., Wang, G.F., \& Goddard, W.A., 2005. A Structure of PAMAM Dendrimers: Generation 1 Through 11. Macromolecules, 37:6236-6254.

8. Mandal, T., Dasgupta, C., \& Maiti, P.K., 2013. Engineering Gold Nanoparticle Interaction by PAMAM Dendrimer. The Journal Physical Chemistry.

9. Anonim, 2013. Dendrimer library https://sites.google.com/site/dendrimer library/home diakses 3 april 2015 
Kajian Dendrimer (Poly)Amidoamine (Pamam) Generasi 4 Sebagai Template Dalam Pembentukan Nanopartikel Secara In Silico

10. Maingi, V., Jain, V., Bharatam, P.V., \& Maiti, P.K., 2012. Dendrimer Building Toolkit: Model Building and Characterization of Various Dendrimer Architectures J. Comput. Chem.33, 1997-2011
11. Nurbaiti, S., 2009. Stabilitas Termal dan Pergerakan Dinamis Klenow-Like DNA Polimerase I ITB-1 Berdasarkan Simulasi Dinamika Molekul. Disertasi. Program Studi Kimia Institut Teknologi Bandung 